\title{
Determination of content of distance course of physics for secondary school
}

\author{
Nina V. Kochergina ${ }^{1, *}$, and Aleksandr A. Mashin'ian ${ }^{1}$ \\ ${ }^{1}$ ISED RAE, Centre of Natural Science Education, 105062, Moscow, Russia
}

\begin{abstract}
The approaches to the organization of e-learning in Russian schools are described in this article. The selection of a content of physics course for distance learning on the basis of three factors: a nature of a physics course, peculiarities of distance learning and laws of creation of learning tools is discovered in it. A model of a physics course for distance learning is presented in this article. An example of realization of the model of the physics course for distance learning for students of the 7 th grade is given in it. The authors outline prospects of development of the content of general education courses and enlarging the number of students taking distance learning.
\end{abstract}

Distance learning technologies (DLT) and e-learning (EL) were firmly included in the system of Russian education at all levels: from general secondary education to higher vocational one. It was facilitated by the rapid development of computer-based tools and technologies that allowed creating numerous digital educational resources (DER) of various quality and complexity for all school disciplines. DER are supposed to be used to design informational and educational environment (IEE) and use it for distance education of secondary and higher school students. Initially, in the 90 -ies, IEE was created to use digital resources in a traditional (full-time) learning process.

Distance learning (DL) is treated as a type of learning based on educational interaction between teachers and students being far away from each other in a broad sense. "This is a form of learning in which interaction between teachers and students and students among themselves is carried out at a distance and reflects all the inherent components of the educational process (aims, content, methods, organizational forms, learning tools) that are implemented by specific means of Internet technologies or other means of providing interactivity," [1, p. 17].

We consider DE, on the one hand, as a type of educational activity, and, on the other, as a form of general education of a student by an entity engaged in educational activities at an appropriate level. Moreover we are not inclined to reduce distant learning to elearning, and especially to a set of distant learning technologies. We consider both of themes as possible tools and technologies for distance delivery of educational programs by an institution, i.e. as distance learning. In this regard, we treat distancet learning as a form of extra mural learning of students receiving general education. Their availability at school is a necessary organizational requirement but it is not a sufficient pedagogical factor for effective implementation of all requirements of Federal state educational standard (FSES) in the process of distance (not full-time) learning.

The social demand for distance learning has significantly increased in Russia. It is mainly explained by high level of diseases among children which often make them stay out of school, as well as a significant number of Russian students temporarily residing outside Russia.

To meet this social demand, the Ministry of Education and Science has initiated the adoption of laws and decrees regulating distance learning in general education:

1. Federal Law of 29 December 2012 No. 273-FZ "On education in the Russian Federation", part 2 of Art.16.

2. Order No. 2 of the Ministry of Education and Science of the Russian Federation "On approval of Procedure of use of e-learning, distance educational technologies in implementation of educational programs by organizations engaged in educational activities" dated 09.01.2014 [2].

3. Proceedings of the State Council meeting held in December 2015.

The basic documents of the Government, the Ministry of Education and Science underline the necessity of introduction of distance learning in the framework of the unified informational and educational environment.

We have identified at least three approaches to its introduction in Russian schools after analyzing hundreds of websites of schools implementing distance learning, The First approach involves teaching students only

* Corresponding author: kachergina@mail.ru 
within a school. The following actions are taken to do this:

1. A school website should provide links to digital resources for DL.

2. Digital resources should be attached as a classroom and (or) homework assignment to an electronic journal.

3. Digital resources should be hosted on a teacher's website.

4. Completed assignments should be scanned and sent to a teacher for verification.

5. On-line testing of students.

6. Consultations for students during video conferences (on-line communication).

Distance learning in public schools is organized by an administration and teachers quite spontaneously and has no solid scientific basis. Material and technical conditions of distant learning are often presented on a teacher's website by well-selected DER. As a rule, a learning material is systematically selected in commercial centers. In general, we can say that the scientific and methodic conditions for organizing distance learning are only partially created.

The Second approach involves teaching through online schools. In this case:

1. Students learn the material using the Interneturok website and perform the teacher's tests in any form.

2. Students sign up on the Interneturok website and get access to simulators and tests, print the performed test with the scores and bring it to the teacher.

3. For performing final tests, students have to come to school personally.

Let us find out which online schools are currently operating. Websites analysis allows us to highlight the largest e-school in Russia "Extern-Mos" [3]. It provides possibility to receive officially systematic general education for all students in Moscow and the Moscow region. This is an online school in which almost all the subjects may be mastered in the form of distance teaching. Moreover, a substantial amount of studies is conducted in the regime of video conference. School programs allow to a great extent to combine the advantages of external studies with opportunities and benefits of distant education. However, there are no classes in the distant learning environment of this school on the following subjects: physical education, music, fine arts, no laboratory works in physics and chemistry. Learning in this online school is paid one. Final tests are performed by students in public and private schools in Moscow, so it is almost impossible for people from all other parts of Russia to study there.

"Home school" [4] is another commercial institution which has got teaching material on all subjects for primary, basic and secondary general education. Its website hosts free accessible video lessons of various qualities and abstracts of lessons, and supervising tests are available in closed access. The latter means that one needs to register at the website in order to be able to work with simulators and to perform tests. To obtain a diploma of secondary education one should be officially linked to a partner school. Students pass the final faceto-face examination in this school.

The Third approach is learning at online schools with the final face-to-face control exam at a basic school. For this purpose:

1. Students officially enter the Home School on the website "Extern-Mos".

2. They take lessons with teachers via video conference and perform their tests.

3. The final control exam is to be carried out in faceto-face manner in a partner school.

4. A school must enter into a partnership agreement with the Home School.

If a school has no its own database of digital educational resources to implement systematic distance education, its management should sign a partnership agreement with an online school that has such a database. This is the way distance learning is implemented in some schools of Moscow, St. Petersburg, Lipetsk and other towns. We'd like to note that private schools are the most successful ones in implementing this type of education.

Selection and justification of the content of general secondary education were considered in works of Russian didactics working under the leadership of V. V. Kraevskii and L. J. Lerner, in the 70-es of the last century.

According to the didactics approach, the content of education is determined by:

- based on sources - objects, the content of which in some sense becomes a content of education;

- taking into account factors - circumstances that affect a content of education;

- principles indicating general direction of development of the education content;

- criteria which govern the procedure of development, selection of learning material, its consistency [5, p. 200].

Moreover, the education is content selected at three levels: the theoretical level, the level of school subject and the level of educational material. What level the content of learning objects for distance learning should be selected at? It is clear that, with the adoption of the new FSES with exemplary programs, which provide the content of all academic subjects for general secondary education, the first two levels have already been formed. The third level has traditionally been entrusted to school teachers, or, at best, to specialists in the field of theory and methodology of teaching physics. In this regard, we reserve the right to change, taking into account the specifics of DL, the structure of educational level of the school subject and give content to the DL physics course at the level of teaching material.

In addition, since the DL is often regarded as a type or form of learning, there is no need to consider the whole procedure of development of education content of a specific academic subject, beginning from the theoretical level. It is enough to consider its selection at the level of academic subject and educational material taking into account three main factors:

- the specifics of the academic subject;

- the features of distance learning;

- the laws of learning tools creation. 
Let us review the process of development of the content of an academic subject through the example of physics course at school. The leading component of the academic subject "Physics" is the subject knowledge. Therefore, this course should include the system of physical knowledge.

The academic subject of Physics is studied in the national school by three cycles: propaedeutic in grades 7-8, pre-teaching in grade 9 and profile in grades 10-11. The first two cycles are studied in primary school. They are characterized by phenomenological and experimental characters. In senior school, the physics course is presented in a theoretical way in which the knowledge is systematized around fundamental physical theories. According to the classification by V. Heisenberg, there are four fundamental physical theories: classical mechanics, statistical physics, classical electrodynamics and quantum physics. In this regard, the courses in physics for senior school (grades 10-11) are divided into four sections: "Foundations of classical mechanics", "Molecular physics and thermodynamics", "Fundamentals of classical electrodynamics" and "Fundamentals of quantum physics". This clear structure of the physics course allows implementing the basic principle of distance learning - the principle of consistency or modularity. According to this principle, the material of the learning course is divided into relatively large modules, which provide basic information about the subject at the level of facts, experiments, concepts and laws. At the beginning and the end of the study of a module, one should provide an element-based control of learning all the concepts and laws, and, also at the end of a module, a compulsory procedure for the synthesis of knowledge should be taken.

Let us find out which principles can be taken as a basis for creation of a content of physics courses for distance learning. In her study, E.S. Polat defines the specific principles of distant learning:

1) the principle of consistency defines the entire organization, including a design of teaching, creation of the system of means of teaching, i.e., teaching tools, and organization of cognitive activity itself;

2) the principle of consideration of a specific subject area of study and characteristics of students;

3) the principle of interactivity allows to use telecommunications to organize systematic contact between a teacher and students in teaching process;

4) the principle of flexibility and agility of the entire educational process and educational and methodical support, which is often implemented by using a modular structure of content, in accordance with the needs and interests of individual students;

5) the principle of the team spirit, team approach to organization of activities in the networks;

6) the principle of informational and psychological security [1].

Many of the above principles are beyond the framework of DL, they constitute general pedagogical principles, or even philosophical ones extrapolated on the area of distance learning, for example, the principle of consideration of the specific subject area of study and characteristics of students and the principle of consistency, respectively. Some of the principles, by contrast, are a special case of the general principles of any practical activity discussed above, such as the principle of interactivity which is a part of the principle of communicativeness. The principles such as team spirit and team approach are common to any innovative educational activities and implemented there and then, where and when the authoritarian approach to school education is terminated.

The specifics of Physics as a general education subject lies in its practical and experimental orientation. It leads to necessity of inclusion in a school course of physics of a large array of physical tasks, organization of workshops on solving tasks in each topic, demonstration and laboratory experiments.

Implementation of the above conditions is based on the principle of interactivity, namely: all educational interaction is carried out by using telecommunication systems and digital resources. In physics, specialists have already developed banks of tasks of different level of complexity: from training, including on-line tests, to more sophisticated tasks and tasks for inter-school competitions. The texts and solutions of tasks of increased complexity were published, for example, on the websites of the journals "Kvant" and "Fizmatbank". In addition, there are quite a number of resources for virtual labs developed by "Fizikon" firm and by teachers themselves.

The interactive physical models will not make it possible to generate experimental skills in full. In this regard, it is necessary to have sets of physical equipment for each class in each school that can be given to students "for rent", as books in the library. School libraries should be replaced by multimedia libraries with resource centers for "rental out" sets of laboratory equipment. If the number of students is large, it is advisable to arrange face-to-face laboratory works carried out on schedule, for example, before a test in each module.

The practices of distance learning show that the knowledge and skills of students are quite different in quality. The flexibility and mobility of the educational process allows you to quickly find gaps in knowledge, to build each student's individual path of development. It allows guiding him to study one or another module content with the selection of a particular form of control.

The principle of team spirit has shown its effectiveness in terms of mutual enrichment experiences, sharing of digital resources and ideas on the organization of distant learning. However, one should have a critical eye on the process of such "mutual enrichment", as many resources are not of high quality. Much more efficient this process proceeds in the presence of methodological centers and teaching unions. In Moscow, district methodical centers were abolished with transferring their functions to the city center and introducing a position of Methodist in each school. As a result, the effectiveness of methodical work has decreased as the number of teachers per one city Methodist has increased tenfold, while school Methodists do not know all private subject methods. 
The principle of information and psychological security is extremely important now. Its influence on the content of the distance course of physics for general education affects primarily the resources obtained by teachers from the Internet. Among them are not only the resources with the physical and methodological mistakes, but also those having anti-social, even antiRussian orientation. For example, there was a resource for the study of the law of conservation of momentum of anti-Russian orientation, which has been in free access for a long time.

However, methodological errors are often found in the material of systematic courses of school subjects presented on the websites. For example, the site Interneturok offered physics lessons, where a teacher writes with chalk on a Board and this Board is the only thing demonstrated. The most common disadvantages of this resource are: 1) a teacher presents the material very quickly, without intonation accents, almost as a tongue twister; 2) a teacher demonstrates a physical experiment and holds the equipment on the background of the his own figure but not against a screen. The advantages of these lessons are low, because the laws of creation of educational films with demonstration of experiments are violated. In this connection, another principle of forming the content of the distance course of physics is as follows: one should take into consideration the laws of creation of educational films, interactive tables, and overall patterns of creating science learning tools.

The overall situation is quite contradictory. Teaching in all schools is based on the textbooks approved by Ministry of Education. They all passed the examination for compliance with the requirements of the FSES. Even digital applications to textbooks have passed such examination. But teaching in online schools is organized quite differently. There are digital resources that have not passed any examination, neither sanitary nor pedagogical one.

The need of such examination was noted by us previously [6]. Sanitary-and-hygienic examination is a compulsory one; it is required because teaching affects the health of children. Pedagogical expertise in our country is voluntary, but it influences the quality of knowledge and skills obtained by students and, consequently, the level of competences formed. However, the companies that create digital resources often neglect pedagogical expertise due to the lack of "political will". As a result, there are a lot of digital educational resources of very poor pedagogical quality.

Consideration of these principles and laws will allow you to create the electronic model of the physics course for distance learning devoid of weaknesses identified (Table.1).

Table 1. A model of physics course for distant learning.

\begin{tabular}{|l|l|l|}
\hline DE principles & $\begin{array}{l}\text { Features of the subject } \\
\text { "Physics" }\end{array}$ & \multicolumn{1}{|c|}{$\begin{array}{c}\text { Generalities of learning tools } \\
\text { creation }\end{array}$} \\
\hline Systemacity & $\begin{array}{l}\text { Synthesis of the material } \\
\text { around fundamental } \\
\text { physical theories }\end{array}$ & $\begin{array}{l}\text { Creation of a system of learning } \\
\text { tools }(\mathrm{LT}) \text { in the physics course } \\
\text { and sets of LT for each theory. }\end{array}$ \\
\hline Interactivity & $\begin{array}{l}\text { Availability of practical } \\
\text { and experimental } \\
\text { component }\end{array}$ & $\begin{array}{l}\text { Creation of digital resources } \\
\text { database: e-tasks,simulators and } \\
\text { virtual laboratory works for each }\end{array}$ \\
\hline
\end{tabular}

\begin{tabular}{|l|l|l|}
\hline $\begin{array}{l}\text { Flexibility and } \\
\text { agility }\end{array}$ & $\begin{array}{l}\text { Building a modular } \\
\text { structure of the course } \\
\text { and individual pathways } \\
\text { of development }\end{array}$ & $\begin{array}{l}\text { Creation of learning tools sets for } \\
\text { each course module. } \\
\text { Creation of integrated LT to } \\
\text { overcome each cognitive barrier }\end{array}$ \\
\hline Team spirit & $\begin{array}{l}\text { Active interaction } \\
\text { between teachers aimed } \\
\text { at exchange of digital } \\
\text { resources and distance } \\
\text { learning technologies. }\end{array}$ & $\begin{array}{l}\text { Creation of thematic network } \\
\text { forums for interaction between } \\
\text { teachers and consulting centers } \\
\text { within school associations, } \\
\text { counties, cities, etc. }\end{array}$ \\
\hline $\begin{array}{l}\text { Information } \\
\text { and } \\
\text { psychological } \\
\text { security }\end{array}$ & $\begin{array}{l}\text { Pedagogical expertise. } \\
\text { Creation of expert } \\
\text { centers or expert } \\
\text { examinations in the } \\
\text { framework of methodical } \\
\text { or school associations. }\end{array}$ & $\begin{array}{l}\text { Interaction with scientific } \\
\text { community to examine the learning } \\
\text { tools in the framework of pilot sites, } \\
\text { research and teaching centers and } \\
\text { laboratories, scientific research } \\
\text { institutes. }\end{array}$ \\
\hline
\end{tabular}

Let us consider how the implementation of a model of physics course will look like for distant learning through the example of 7th grade. The grade 7 Physics course contains 5 sections, according to which modules are identified:

1. The subject of physics. Measurement of physical quantities.

2. Initial information about the structure of matter.

3. Interaction of bodies.

4. Pressure of solids, liquids and gases.

5. Work and power. Energy.

For each module, the electronic content of lessons is composed. As an example, the table shows the content of the lessons of several topics of the third module "Interaction of bodies" (Table.2).

At the end of each module, a final control is carried out, and at the end of each semester - a full-time control, for example, a test work on major issues of the topic.

Table2. An example of electronic content of a physics course for distance learning

\begin{tabular}{|c|c|c|c|}
\hline $\begin{array}{c}\text { Topic } \\
\text { No. }\end{array}$ & $\begin{array}{c}\text { Title of topic, } \\
\text { basic concepts } \\
\text { and laws }\end{array}$ & $\begin{array}{l}\text { Electroniccontentof } \\
\text { topic }\end{array}$ & Tasks forstudents \\
\hline 1. & $\begin{array}{l}\text { Mechanical } \\
\text { movement. } \\
\text { Trajectory, } \\
\text { relativity of } \\
\text { mechanical } \\
\text { movement }\end{array}$ & $\begin{array}{l}\text { 1) Info Lesson } 7 \text { grade; } \\
\text { 2) printed workbook; } \\
\text { 3) electronic version of } \\
\text { collection of tests }\end{array}$ & $\begin{array}{l}\text { 1) study the topic using the } \\
\text { Info Lesson resource; } \\
\text { 2) perform the task to } \\
\text { paragraph } 14 \text { in the workbook; } \\
\text { 3) perform test } 4 \text {, scan and } \\
\text { send it to the teacher }\end{array}$ \\
\hline 2. & $\begin{array}{l}\text { Even and } \\
\text { uneven } \\
\text { movement }\end{array}$ & $\begin{array}{l}\text { 1) Online Lesson:topic } \\
9 \text { - video; } \\
\text { 2) online simulators; } \\
\text { 3) online tests }\end{array}$ & $\begin{array}{l}\text { 1) study the video at the Online } \\
\text { Lesson resource; } \\
\text { 2) use online simulators to } \\
\text { perform tasks; } \\
\text { 3) pass online test }\end{array}$ \\
\hline 3. & $\begin{array}{l}\text { Density. } \\
\text { Density units. } \\
\text { Calculation of } \\
\text { mass and } \\
\text { volume of a } \\
\text { body by its } \\
\text { density }\end{array}$ & $\begin{array}{l}\text { 1) Info Lesson; } \\
\text { 2) electronic version of } \\
\text { collection of tests; } \\
\text { 3) virtual labs }\end{array}$ & $\begin{array}{l}\text { 1) study the topic in the Info } \\
\text { Lesson resource; } \\
\text { 2) perform a test for the topic; } \\
\text { 3) do the virtual lab work and } \\
\text { send it to the teacher }\end{array}$ \\
\hline
\end{tabular}

When creating electronic content of a physics course, a teacher creates a prototype of an electronic textbook for the subject. Is there a need for such textbooks, if the leading publishers currently release e-textbooks that have been reviewed for compliance with the FSES? Yes. First, because all the electronic tutorials are created for full-time study. Second, the e-content of topics created 
by a teacher are best adapted to his students and takes into account the specifics of a particular class.

Another argument in favor of the necessity for a teacher to design independently the content of distant learning courses is a significant dependence of the electronic content of school subjects on the level of electronic equipment of the educational organization. None of the electronic textbooks may take into account this specificity. In addition, distance education technologies are being improved following the development of electronics, and this also affects the equipping of educational institutions.

What can be done to increase the number of students studying remotely? This question is often the first one for the administration of an organization which decided to establish distance learning. One can use, firstly, the internal resources of each school, namely: officially to transfer to distance learning the following students:

- those subjected to seasonal diseases in light form;

- those travelling with parents during the learning period;

- those who missed classes due to family circumstances.

It is easy to expand the list of the internal resources to be used.

Significant expansion of the number of students taking distance learning is possible by involving external resources by:

- signing of partnership agreements with the Home School;

- advertising the advantages of distance learning on the school website and in the media;

- inviting foreign citizens, which is especially important for countries with many ethnic Russians and foreign citizens who are interested in Russian culture and education (e.g. China);

- attracting students who, for one reason or another, are willing but can't take the advantage of the full-time form of education in a private school by primary or secondary education program.

Thus, the selection of the content of a physics course for distance learning should be implemented:

- taking into account three factors (specificity of the course of physics, the characteristics of distance learning and the laws of creation of learning tools);

- at two levels (of the academic subject, changing its structure, and of the learning material).

Over the years, the number of students taking distance learning will inevitably increase. The content of distance educational courses should continuously be improved. A model of physics course for distance learning at school allows the teacher to independently generate the electronic content of the school subject

\section{References}

1. E.S.Polat, M.Yu.Bukharkina, and M.V.Moiseeva, Teoriya $i$ praktika distantsionnogo obucheniya (Akademiya, Moscow, 2004) [In Rus]

2. Minobrnauki RF, «Ob utverzhdenii Poryadka primeneniya organizatsiyami, osushchestvlyayushchimi obrazovatel'nuyu deyatel'nost', elektronnogo obucheniya, distantsionnykh obrazovatel'nykh tekhnologii pri realizatsii obrazovatel'nykh programm» prikaz № 2 ot 09.01.2014. Available online: URL http://www.edu.ru/db/mo/Data/d_14/m2.pdf (accessed on 04.03.14) [In Rus]

3. Internet-shkola Mos-Ekstern. Available online: URL http://extern-mos.ru/internet-school (accessed on 13.02.16 [In Rus]

4. Domashnyaya shkola. Available online: URL http://interneturok.ru (accessed on 15.09.15 [In Rus]

5. V.V.Kraevskii, and I.Ya.Lerner, Teoreticheskie osnovy soderzhaniya obshchego srednego obrazovaniya (Pedagogika, Moscow, 1983) [In Rus]

6. A.A.Mashin'yan, and N.V.Kochergina, Sistemnotekhnologicheskii podkhod $v$ optimizatsii soderzhaniya uchebnogo predmeta «Fizika» (obshchee obrazovanie) (ISMO, Moscow, 2014) [In Rus] 